\title{
100-YEAR-OLD HAEMATOLOGICA IMAGES: THE QUARREL ABOUT THE ORIGIN OF PLATELETS (III)
}

\section{Carlo L. Balduini}

Ferrata-Storti Foundation, Pavia, Italy

E-mail: CARLO L.BALDUINI - carlo.balduini@unipv.it

doi:10.3324/haematol.2020.256974

T he fascinating story of platelets began in 1881 when Giulio Bizzozero identified these cells in peripheral blood and demonstrated that they play a key role in the hemostatic process. ${ }^{1} \mathrm{He}$ also observed that leukocytes are recruited into the platelet aggregates and offered the first images of platelet-leukocyte interaction. Bizzozero's successes in the study of platelets are not limited to these discoveries. In fact, twelve years earlier he had described for the first time megakaryocytes, which for a long time were called "Bizzozero's giant bone marrow cells". ${ }^{2}$ However, he never recognized the close links between platelets and megakary-

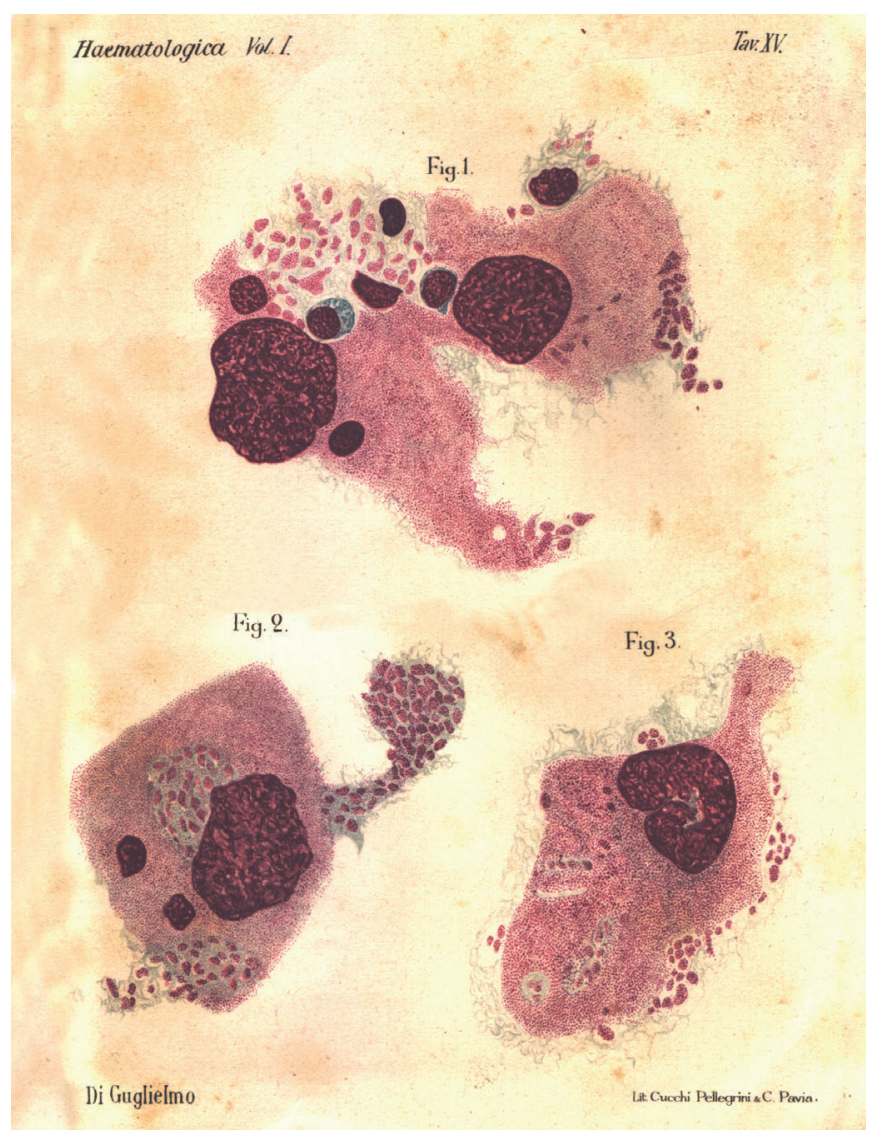

Figure 1. Hand-drawn color plate illustrating the Di Guglielmo paper entitled "Platelets and megakaryocytes" published in Haematologica in 1920. In this article, Di Guglielmo presented evidence to support the idea put forward by Wright that platelets are formed by megakaryocytes, a concept that was the subject of heated debate at the time. ocytes. This was identified in 1916 by James Homer Wright, who noted the similarities in shape and color of the granules of megakaryocytes and platelets using his new polychrome staining technique: Wright's stain. ${ }^{3}$ Moreover, by microscopy analysis of bone marrow sections, he showed platelets budding from megakaryocytes and entering the circulation. ${ }^{4}$ However, despite this evidence, the origin of platelets was still under discussion at the time of the first issue of Haematologica in 1920.5.7

Strong support for the derivation of platelets from megakaryocytes was given by an article published by Giovanni Di Guglielmo in the first issue of Haematologica. ${ }^{8}$ At that time, Di Gugliemo was a young assistant to Adolfo Ferrata, the founder of Haematologica, at the Medical Clinic of Naples. (Interestingly, after the death of Ferrata in 1946, Di Guglielmo was the Editor of the journal until 1960.) This paper, entitled "Megakaryocytes and platelets", reported the presence of rare megakaryocytes in blood films of patients with chronic myeloid leukemia. Morphological evaluation of these cells revealed that megakaryocytes release platelets by two mechanisms (Figure 1): through the formation of long cytoplasmic extroflexions and by the direct fragmentation of cytoplasm (Figure 1). Both mechanisms have been confirmed in this new millennium. ${ }^{9,10}$ The finding that circulating megakaryocytes are involved in platelet formation was also recently confirmed. ${ }^{11}$

\section{References}

1. Bizzozero, G. [Su di un nuovo elemento morfologico del sangue dei mammiferi e sulla sua importanza nella trombosi e nella coagulazione]. L'Osservatore Gazz Clin. 1881;17:785-787

2. Bizzozero, G. [Sul midollo delle ossa]. Il Morgagni. 1869;11:617-646.

3. Wright JH. The origin and nature of blood platelets. Boston Med Surg J. 1906;154:643-645

4. Wright JH. (1910) The histogenesis of the blood platelets. J Exp Med. 1910;21:263-278.

5. Mazzarello P. One hundred years of Haematologica. Haematologica. 2020;105(1):12-21.

6. Balduini CL. 100-year old Haematologica images: The quarrel about the origin of platelets (I). Haematologica. 2020;105(5):1169.

7. Balduini CL. 100-year old Haematologica images: The quarrel about the origin of platelets (II). Haematologica. 2020;105(6):1467.

8. Di Guglielmo G. [Megacariociti e piastrine]. Haematologica. 1920;1:303332

9. Nishimura S, Nagasaki M, Kunishima S, Sawaguchi A, Sakata A, et al. IL-1 $\alpha$ induces thrombopoiesis through megakaryocyte rupture in response to acute platelet needs. J Cell Biol 2015;209(3):453-466.

10. Italiano JE Jr, Lecine P, Shivdasani RA, Hartwig JH. Blood platelets are assembled principally at the ends of proplatelet processes produced by differentiated megakaryocytes. J Cell Biol. 1999;147(6):1299-1312.

11. Lefrançais E, Ortiz-Muñoz G, Caudrillier A, et al. The lung is a site of platelet biogenesis and a reservoir for haematopoietic progenitors. Nature. 2017;544(7648):105-109. 